\title{
Correction to "Structure of the Complex of an Iminopyridinedione Protein Tyrosine Phosphatase 4A3 Phosphatase Inhibitor with Human Serum Albumin"
}

In the above article [Czub MP, Boulton AM, Rastelli EJ, Tasker NR, Maskrey TS, Blanco IK, McQueeney KE, Bushweller JH, Minor W, Wipf P, Sharlow ER, and Lazo JS (2020) Mol Pharmacol, 98: 648-657; DOI: https://doi.org/10.1124/molpharm.120.000131], the first display equation on page 651 contained errors and was placed incorrectly in the layout. The corrected equation is:

$$
\begin{aligned}
W=\left\{\left(\frac{[\text { JMS-053 }]}{[\text { serum albumin }]}+\frac{\mathrm{K}_{\mathrm{D}}}{[\text { serum albumin }]}+1\right)\right. \\
\left.\quad-\sqrt{\left(\frac{[\text { JMS-053 }]}{[\text { serum albumin }]}+\frac{\mathrm{K}_{\mathrm{D}}}{[\text { serum albumin }]}+1\right)^{2}-4\left(\frac{[\text { JMS-053 }]}{[\text { serum albumin }]}\right)}\right\} / 2
\end{aligned}
$$

The HTML and PDF versions of the article have been corrected.

The compositor apologizes for any inconvenience caused by the errors. 